\title{
Analysis of Genetic Diversity Between Eriobotrya japonica (Thunb.) Lindl. (Rosaceae) Populations Growing in the Aegean Region of Turkey
}

\author{
Emre SEVINDIK*, Kemalcan OKAN, Fadime EFE \\ Department of Agricultural Biotechnology, Faculty of Agriculture, Adnan Menderes University, South \\ Campus, Cakmar, Aydin, Turkey \\ *corresponding author: ph.d-emre@hotmail.com
}

Bulletin UASVM Horticulture 77(2) / 2020

Print ISSN 1843-5254, Electronic ISSN 1843-5394

DOI:10.15835/buasvmcn-hort: 2020.0012

\begin{abstract}
In this study, we performed a genetic diversity using RAPD (Random amplified polymorphic DNA) and ISSR (Inter-simple sequence repeats) markers for some Eriobotrya japonica populations grown in the Aegean region of Turkey. PCR was performed with all DNA samples and primers with ability of scoring band. Phylogenetic analysis and pairwise genetic distance between the populations were calculated by using the PAUP analysis program. According to the RAPD data, a total of 33 bands were obtained and 21 of them were polymorphic. The closest genetic distance (0.09677) was found between Aydın and Nazilli populations, while the most distant value was found 0.44000 between Salihli and Nazilli populations. According to the ISSR data, a total of 43 bands were obtained and 18 of them were polymorphic. The closest genetic distance (0.09302) was found between İzmir and Aydın populations, while the most distant values (0.48276) were found between Denizli and Nazilli populations. As a result of this study, the rate of polymorphism obtained in ISSR technique was found to be lower than the RAPD technique.
\end{abstract}

Key Words: Eriobotrya japonica, genetic diversity, ISSR, RAPD

\section{Introduction}

The Rosaceae family currently contains about 100 genera and 3000 species (Potter et al., 2007a; Pang et al., 2011). The family, which generally contains taxa in the form of tree and bush, has herbaceous taxa as well. Cosmopolitan family members mostly spread in the northern hemisphere. The taxa of the Rosaceae family spread in almost all kinds of habitat, on the other hand, they can live as a pioneer species in the early stages of forest succession or in forest-front habitat (Hummer and Janick, 2009; Serdar et al., 2014). Rosaceae is one of the most economically important families of flowering plants that contain many species grown for their fruits and ornamental plants (Morgan et al., 1994). Eriobotrya japonica (Thunb.) Lindl. belongs to the Rosaceae family
Maloideae subfamily and is a perennial plant. The origin of loquat was China, Japan and North India (Xinaghui et al., 2012; Toker et al., 2010). However, in Cyprus, Egypt, Greece, Israel, Italy, Spain, Tunisia and Turkey is grown loquat also.

According to 2003 data, there are 288,000 loquat trees in Turkey (Taskın and Erdal, 2011). Loquat leaves and fruits are traditionally used to treat coughs and phlegm; and its flower is a perfect source of honey (He et al., 2011). Molecular markers, have a significant role in agricultural reproduction programs. Reaching significant information about the heredity of genetic and economically important plant species in a short period of time has been possible by means of the studies on molecular markers so far (Kalkışım et al., 2016; Aksu and Sahin-Çelik, 2015). Molecular 
characterization is conducted with DNA-based molecular markers such as RAPD and ISSR, which are not affected by environmental factors and are more polymorphic (Sharma et al., 2017). RAPD first emerged as a technique which is based on Polymerase Chain Rectification (PCR) with the use of randomly selected primers in 1990 (Williams et al., 1990). It is possible to use these markers to detect DNA polymorphism without the need for pre-determined genetic information (Sharma et al., 2017). RAPD technique is used in population genetic, systematic and taxonomic classification studies (Coşkun and Parlak, 2013). The ISSR technique (Zietkiewicz et al., 1994) is very similar to the RAPD technique, but ISSR primers are designed from microsatellite regions. However, the ISSR technique has more useful information than the RAPD technique. The biggest advantage of the ISSR technique is that it is not necessary to know the genome sequence for the design of primers (Khorshidi et al., 2017). The aim of the study was to determine by use of RAPD and ISSR-PCR techniques for five Eriobotrya japonica populations genetic diversity grown in the Aegean region of Turkey.

\section{Material and Methods}

Plant Materials, DNA Isolation and PCR

Five Eriobotrya japonica population samples were collected from Denizli, Aydın, İzmir, ManisaSalihli and Aydin-Nazilli hills and districts of the Aegean region and brought in laboratory silica jellies. Total genomic DNA isolation from the leaves of Eriobotrya japonica was performed using commercial kit (GeneMark). DNA samples were stored $-20{ }^{\circ} \mathrm{C}$. In order to visualize gDNA's $1.0 \%$ standard agarose gel electrophoresis procedure was performed. For RAPD-PCR amplification six RAPD primers were used (Tab. 1). RAPD amplification reactions were carried out in 25 $\mu \mathrm{l}$ volume containing $5 \mu \mathrm{L}$ master mix [Cat. No: RP02-II-400, RP02-II-2000 (0.75U of Taq DNA polymerase, reaction buffer, $2 \mathrm{mM} \mathrm{MgCl}_{2}$, $250 \mu \mathrm{M}$ dNTPs and enzyme stabilizier)], $1 \mu \mathrm{L}$ RAPD primers, $2.0 \mu \mathrm{l}$ of total genomic DNA $(1 / 5$ rates diluted), and $17 \mu \mathrm{L}$ of $\mathrm{dH}_{2} \mathrm{O}$. The RAPDPCR protocol is shown in Table 1 . For ISSR-PCR amplification eight ISSR primers were used (Tab. 2). ISSR amplification reactions were carried out in $25 \mu \mathrm{l}$ volume containing $5 \mu \mathrm{L}$ master mix [Cat. No: RP02-II-400, RP02-II-2000 (0.75U of Taq

Table 1. Primers used in the RAPD-PCR reactions and PCR Amplification

\begin{tabular}{|c|c|c|}
\hline Primer & DNA Sequences & $\begin{array}{c}\text { PCR Amplification } \\
\text { (35 Cycles) }\end{array}$ \\
\hline OPA-15 & 5'-TTCCGAACCC-3' & \multirow{6}{*}{$\begin{array}{c}94^{\circ} \mathrm{C} / 2 \mathrm{~min} \\
94^{\circ} \mathrm{C} / 1 \mathrm{~min} \\
32-34^{\circ} \mathrm{C} / 1 \mathrm{~min} \\
72^{\circ} \mathrm{C} / 1 \mathrm{~min} \\
72^{\circ} \mathrm{C} / 10 \mathrm{~min}\end{array}$} \\
\hline OPA-02 & 5'- TGCCGAGCTG -3' & \\
\hline OPE-08 & 5'-TCACCACGGT-3' & \\
\hline OPA-16 & 5'-AGCCAGCGAA-3' & \\
\hline OPA-18 & 5'-AGGTGACCGT-3' & \\
\hline OPA-13 & 5'- CAGCACCCAC-3' & \\
\hline
\end{tabular}

Table 2. Primers used in the ISSR-PCR reactions and PCR Amplification

\begin{tabular}{|c|c|c|}
\hline Primer & DNA Sequences & $\begin{array}{c}\text { PCR Amplification } \\
\text { (35 Cycles) }\end{array}$ \\
\hline UBC-831 & 5'-СТСТСТСТСТСТСТСТТ-3' & \multirow{8}{*}{$\begin{array}{c}94^{\circ} \mathrm{C} / 1 \mathrm{~min} \\
94^{\circ} \mathrm{C} / 1 \mathrm{~min} \\
50-52^{\circ} \mathrm{C} / 1 \mathrm{~min} \\
72^{\circ} \mathrm{C} / 1 \mathrm{~min} \\
72^{\circ} \mathrm{C} / 10 \mathrm{~min} .\end{array}$} \\
\hline UBC-830 & 5'-TGTGTGTGTGTGTGTGG-3' & \\
\hline UBC-807 & 5'-AGAGAGAGAGAGAGAGT-3' & \\
\hline UBC-826 & 5'-ACACACACACACACACC-3' & \\
\hline UBC-819 & 5'-GTGTGTGTGTGTGTGTA-3' & \\
\hline UBC-853 & 5' - TCTCTCTCTCTCTCTCRT-3' & \\
\hline UBC-855 & 5'-ACACACACACACACACYT-3' & \\
\hline UBC-856 & 5'-ACACACACACACACACYA-3' & \\
\hline
\end{tabular}


DNA polymerase, reaction buffer, $2 \mathrm{mM} \mathrm{MgCl}_{2}$, $250 \mu \mathrm{M}$ dNTPs and enzyme stabilizier)], $1 \mu \mathrm{L}$ ISSR primers, $2.0 \mu \mathrm{l}$ of total genomic DNA $(1 / 5$ rates diluted), and $17 \mu \mathrm{L}$ of $\mathrm{dH}_{2} \mathrm{O}$. The ISSR-PCR protocol is shown in Table 2. Amplification products were analyzed by electrophoresis on $1.0 \%$ agarose gel buffered with 0.5X TBE (Tris-Borate-EDTA).

Data Analysis

The images were used for the evaluation of the results in the analysis of RAPD and ISSR-PCR. In the analysis of the bands formed at the end of the amplification, only the strong bands were taken into consideration. Following the PCR analysis, DNA bands were scored as ' 1 ' in the presence of DNA, ' 0 ' in the absence of DNA and a '?' for missing data. PAUP 4.0b10 software was used to perform phylogenetic analyses using RAPD and ISSR data (Swofford, 2001).

\section{Results and Discussion}

DNA-based markers have many advantages in evaluating genetic diversity (Alansi et al., 2016). RAPD and ISSR markers are two polymerase chain reaction (PCR) based techniques commonly used to predict genetic diversity in many plant species (Giachino, 2020). In the RAPD-PCR analysis, a total of 33 bands were obtained, 21 of them were polymorphic and the rate of polymorphism was approximately $63.63 \%$. PAUP $4.0 \mathrm{~b} 10$ analysis program was used to calculate the phylogenetic trees and genetic distances between populations. According to the PAUP analysis, the closest genetic distance was found 0.09677 between Aydın and Nazilli populations, while the most distant values was found 0.44000 between Salihli and Nazilli populations (Tab. 3). The phylogenetic tree was obtained using the UPGMA algorithm, and the tree consisted of two clades (Fig. 1).

The clade 1 consisted of two subclades. Subclade A consists of Denizli and İzmir populations, subclade B consists of Nazilli and Aydın populations. Clade 2 consisted only of Salihli population. In the ISSR PCR analysis, 43 bands were obtained, 18 of them were polymorphic and the rate of polymorphism was about $41.8 \%$. PAUP $4.0 \mathrm{~b} 10$ analysis program was used to calculate the phylogenetic trees and genetic distances between populations. According to the PAUP analysis,

UPGMA TREE

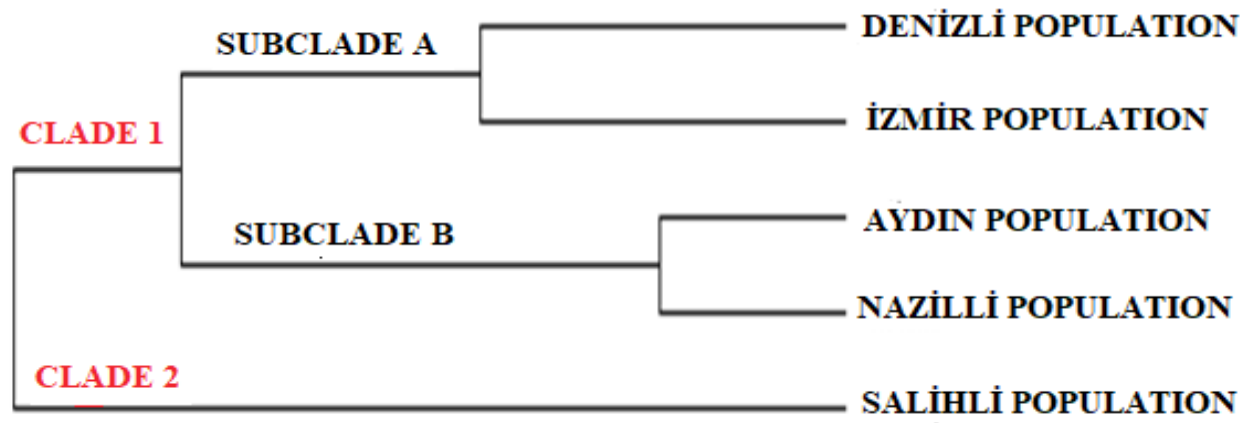

Fig 1. UPGMA dendogram formed through RAPD data in five Turkish loquat populations UPGMA TREE

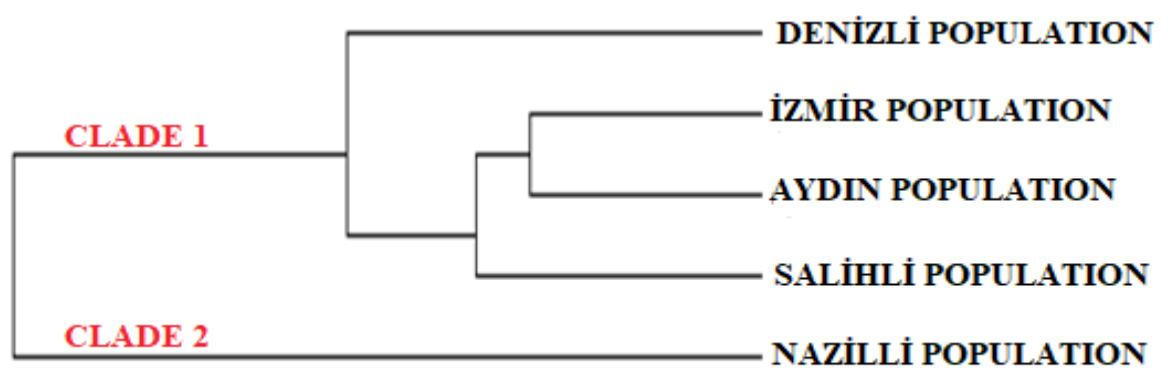

Fig. 2 UPGMA dendogram formed through ISSR data in five Turkish loquat populations 
the closest genetic distance was found 0.09302 between İzmir and Aydın populations, while the most distant values were found 0.48276 between Denizli and Nazilli populations (Tab. 4). The phylogenetic tree was obtained using the UPGMA algorithm, and the tree consisted of two clades (Fig. 2). The first clade consisted of Denizli, İzmir, Salihli and Aydın populations, and the second clade consisted only of Nazilli population.

In the past years there have been many genetic diversity and phylogenetic studies on loquat genotypes using different marker techniques. Vilanova et al. (2001) studied the genetic diversity of loquat cultivars in Spain using the RAPD markers. In the study, the researchers found that RAPD technology is useful in distinguishing cultivars obtained through hybridization. Hussain et al. (2009) detected the genetic diversity of 42 loquat genotypes spread in Pakistan using the RAPD marker technology. The study proved that RAPD markers are a reliable method to reveal the relationship between loquat genotypes. Xie et al. (2007) identified phylogenetic analyses of 17 species of Eriobotrya genus, which spreads in China, using ISSR marker technology. The study also revealed that it was closely related to E. japonica and E. prinoides var. dadunensi. Yang et al. (2009) investigated the genetic relationship of 18 species of Eriobotrya using AFLP marker technique.
The result of the cluster analysis was generally compatible with the known taxonomic grouping. In addition, the cluster of Eriobotrya's 18 accessions is consistent with the systematic classification based on morphological features. Soriano et al. (2005) detected the genetic diversity of 40 cultivars of Eriobotrya japonica obtained from different countries using SSR marker technology. As a result of the study, the researchers showed that the SSRs developed for Malus $\times$ domestica (Borkh.) are suitable for the identification of the loquat variety, confirming intergenus transferability. Xinaghui et al. (2012) investigated phylogenetic relationships of Eriobotrya genus on the basis of nrDNA Adh sequences. The study also includes E. prinoides var. dadunensis and E. japonica were identified within the same group. It was concluded that some species cannot be separated although the $A d h$ gene sequence has a high genetic diversity in Eriobotrya.

\section{Conclusion}

As a result, the genetic diversity of the loquat populations spreading in the Aegean region was determined by RAPD and ISSR markers. As a result of this study, the rate of polymorphism obtained in ISSR technique was found to be lower than the RAPD technique. On the other hand, the obtained results will be a source for further genetic and

Table 3. Pairwise genetic distance matrix obtained from RAPD primers in five Turkish loquat populations

\begin{tabular}{cccccc}
\hline Population & 1 & 2 & 3 & 4 & 5 \\
\hline Denizli & - & 0.18182 & 0.33333 & 0.36364 & 0.38710 \\
\hline İzmir & 6 & - & 0.40741 & 0.36364 & 0.32258 \\
\hline Salihli & 9 & 11 & - & 0.40741 & 0.44000 \\
\hline Aydın & 12 & 12 & 11 & - & 0.09677 \\
\hline Nazilli & 12 & 10 & 11 & 3 & - \\
\hline
\end{tabular}

Table 4. Pairwise genetic distance matrix obtained from ISSR primers in five Turkish loquat populations

\begin{tabular}{cccccc}
\hline Population & 1 & 2 & 3 & 4 & 5 \\
\hline Denizli & - & 0.10345 & 0.17241 & 0.24138 & 0.48276 \\
\hline İzmir & 3 & - & 0.11628 & 0.09302 & 0.27907 \\
\hline Salihli & 5 & 5 & - & 0.11628 & 0.30233 \\
\hline Aydın & 7 & 4 & 5 & - & 0.18605 \\
\hline Nazilli & 14 & 12 & 13 & 8 & - \\
\hline
\end{tabular}


molecular analyses of Eriobotrya japonica populations.

\section{References}

1. Alansi S, Tarroum M, Al-Qurainy F, Khan S, Nadeem M (2016). Use of ISSR markers to assess the genetic diversity in wild medicinal Ziziphus spina-christi (L.) Willd. collected from different regions of Saudi Arabia. Biotechnol. Biotec. Eq, 30(5): 942-947.

2. Aksu MM, Sahin-Çelik M (2015). Moleküler markörlerin meyve islahında kullanım alanları. Meyve Bilimi/Fruit Sci, 2:49-59.

3. Coşkun F, Parlak S (2013). Molecular Phylogenetic Analysis of Olea europaea L. subsp. europaea Cultivars Grown in the Marmara Region, Turkey (Analisis Filogenetik Molekul bagi Kultivar Olea europaea L. subsp. europaea Ditanam di Wilayah Marmara, Turki). Sains Malaysiana, 42: 1357. 1364.

4. Giachino RRA (2020). Investigation of the genetic variation of anise (Pimpinella anisum L.) using RAPD and ISSR markers. Genet. Resour. Crop Ev. 67(3): 763-780.

5. He Q Li XW, Liang GL, Ji K, Guo QG, Yuan WM, Zhou GZ, Chen KS, Eric van de Weg W, Gao ZS (2011). Genetic diversity and identity of Chinese loquat cultivars/accessions (Eriobotrya japonica) using apple SSR markers. Plant Mol. Biol. Rep, 29: 197-208.

6. Hummer KE, Janick J (2009). Rosaceae: Taxonomy, Economic Importance, Genomics. In: K.M. Folta, S.E. Gardiner (eds.), Genetics and Genomics of Rosaceae, Plant Genetics and Genomics: Crops and Models. 6: 1- 17. Springer Science \& Business Media, NY.

7. Hussain A, Abbasi, NA, Hafiz IA, Ahmad Z, Naqvi SS (2009). Molecular characterization and genetic relationship among loquat (Eriobotrya japonica Lindl.) genotypes of Pakistan assessed by RAPD markers. Pak. J. Bot, 41: 24372444.

8. Kalkışım O, Okcu M, Okcu Z, Karabulut B, Yildirim N, Agar G (2016). Relationships among some pears genotypes (Pyrus communis L.) based on ISSR and RAPD analysis. Erwerbs Obstbau, 58: 259-264.

9. Khorshidi S, Davarynejad G, Samiei L, Moghaddam M (2017). Study of Genetic Diversity of Pear Genotypes and Cultivars (Pyrus communis L.) Using Inter-Simple Sequence Repeat Markers (ISSR) Untersuchung der genetischen Diversität von Genotypen und Sorten der Birne (Pyrus communis L.) mit Hilfe von Inter-Simple Sequence Repeat Markern (ISSR). Erwerbs Obstbau, 59: 301-308.

10. Morgan DR, Soltis DE, Robertson KR (1994). Systematic and evolutionary implications of $r b c \mathrm{~L}$ sequence variation in Rosaceae. Am. J. Bot, 81: 890-903.
11. Pang X, Song J, Zhu Y, Xu H, Huang L, Chen S (2011). Applying plant DNA barcodes for Rosaceae species identification. Cladistics, 27:165-170.

12. Potter D, Eriksson T, Evans RC, Oh S, Smedmark JEE, Morgan DR, Kerr M, Robertson KR, Arsenault M, Dickinson TA, Campbell CS (2007a). Phylogeny and classification of Rosaceae. Plant Syst. Evol, 266: 5-43.

13. Serdar B, Karaköse M, Mazlum R, Öztürk M, Çağdaş G, Terzioğlu S (2014). Türkiye'de Doğal Olarak Yetişen Amelanchier Medik. Taksonlarının Odun Anatomileri. BIBAD, 7: 30-33.

14. Sharma H, Vikrant SP, Sharma R (2017). Genetic relationships among Pear genotypes revealed by RAPD and ISSR markers. IJCS, 5: 462-466.

15. Soriano JM, Romero C, Vilanova S, Llácer G, Badenes ML (2005). Genetic diversity of loquat germplasm (Eriobotrya japonica (Thunb) Lindl) assessed by SSR markers. Genome, 48: 108-114.

16. Swofford DL (2001). PAUP. Phylogenetic Analysis Using Parsimony (and other methods), Version 4.0b10.

17. Taskin M, Erdal S (2011). Utilization of waste loquat (Eriobotrya japonica Lindl.) kernel extract for a new cheap substrate for fungal fermentations. Rom. Biotechnol. Lett, 16: 5872-5880.

18. Toker R, Gölükcü M, Tokgöz H, Tepe S (2010). Ülkemizde Yetiştiriciliği Yapılan Önemli Yenidünya (Eriobotrya Japonica) Çeşitlerinin Bazı Kalite Parametrelerinin Belirlenmesi Üzerine Bir Araştırma. Gıda Dergisi, 35: 275282.

19. Vilanova S, Badenes ML, Martínez-Calvo J, Llácer G (2001). Analysis of loquat germplasm (Eriobotrya japonica Lindl) by RAPD molecular markers. Euphytica, 121: 25-29.

20. Williams K, Kubelik R, Livak J, Rafalski A, Tingey V (1990). DNA polymorphisms amplified by arbitary primers are useful as genetic markers. Nucleic Acids Res., 18: 65316535.

21. Xie JH, Yang XH, Lin SQ, Wang W (2007). Analysis of Genetic Relationships Among Erıobotrya Germplasm in China Using ISSR Markers. Acta Hortic, 750: 203-208.

22. Xinaghui Y, Pıng L, Zhike Z, Shunquan L, Guibin H, Xiaolong $H$ (2012). A preliminarily phylogeny study of the Eriobotrya based on the nrDNA Adh sequences. Not Bot Horti Agrobot, 40: 233-237.

23. Yang X, Liu C, Lin S (2009). Genetic relationships in Eriobotrya species as revealed by amplified fragment length polymorphism (AFLP) markers. Sci. Hortic., 122: 264-268.

24. Zietkiewicz E, Rafalski A, Labuda D (1994). Genome fingerprinting by simple sequence repeat (SSR)-anchored polymerase chain reaction amplification. Genomics, 20: 176-183. 